\title{
Online Learning Methods during COVID-19 Pandemic: On an Indonesian Nursing Student Experience
}

\author{
Mamnuah Mamnuah (D), Wantonoro Wantonoro* (D) \\ Department of Nursing, Universitas 'Aisyiyah Yogyakarta, Yogyakarta, Indonesia
}

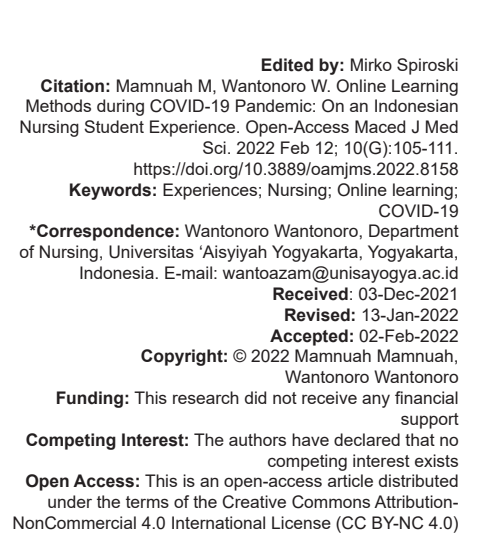

Introduction

Coronavirus disease-19 (COVID-19) was first identified in Wuhan, China, at the end of 2019 [1]. COVID-19 has spread to various countries rapidly, so that on March 12, 2020, the World Health Organization declared COVID-19 as a world pandemic [2]. Based on the data dated on December 2, 2021, COVID-19 has spread to 223 countries in the world and confirmed cases of COVID-19 have reached 262,866,050 with 5,224,519 of them dying [3]. In Indonesia, COVID-19 case is a major concern, because it has not decreased since the first COVID-19 case appeared in Indonesia on March 2, 2020. The total data of confirmed cases in Indonesia on December 3, 2021, have reached 4,257,243 and 143,858 of them have experienced death [4].

With the high rate of COVID-19 transmission, several countries including Indonesia have developed strategies to reduce the spread of COVID-19 by making social distancing rules [5]. One of the enactments of such a rule is the closure of educational institutions nationally, so that as of March 25, 2020, 150 countries have closed educational institutions nationwide [6]. This condition makes all activities in educational institutions that have been planned offline cannot be done, and all of a sudden the learning process must be done online [7]. Online learning is a challenge for the students because the lack of means makes it difficult for the students to access the online learning [8]. The difficulties experienced by the students include the internet quota fees, poor network, inadequate computers, and lack of readiness in online learning between staff and educational institutions [9], [10]. Since March 2020, several universities in Indonesia have conducted online learning. Many students returned to their respective homes with different network conditions, electricity, and social support during the COVID-19 pandemic.

The COVID-19 pandemic has a major impact on the health science students as well, especially on the learning practices that must be done directly on patients to improve the skills and practice in the laboratory [11]. Educational institutions are encouraged to develop curriculum and learning methods to provide opportunities for the students to continue learning to avoid delays in theoretical and practical mastery during the pandemic [12]. The most widely used learning method is direct online lectures by utilizing technology such as Zoom, but for the clinical experience, the lecturers must use very precise methods so that the learning objectives are achieved properly [13] 
The previous research examined the doctors' expectations, stress, and perceptions of COVID-19. More than $80 \%$ of the doctors have hope while $20 \%$ are hopeless. The doctors' hopes include safety guarantees, personal protective equipment facilities, restrictions on routine examinations, maintaining a reserve workforce, and continuing the supply of essential goods [14]. The research through podcast conversations about hopes and fears of the future explains the result that in the shift to online learning, the most prominent fear is the loss of education as an experience. This study also explains the hope that post-colonial universities need to develop a mixed approach for education that safely and flexibly combines virtual with face-to-face teaching to accommodate the diverse needs of the students [15]. Albeit the previous research has explored the doctors' hopes for the pandemic and hopes for the future learning, little empirical evidence has been directed to uncover the students' hopes and needs during the online learning, particularly those investigating the issue using a phenomenological method.

There is also a paucity of research related to the hopes and needs of the health students while undergoing online learning during the pandemic. It does not rule out the possibility that in the future learning process for the health students will still be carried out online. Therefore, it is essential to dig deeper into the hopes and needs of the health science students while undergoing online learning during a pandemic to improve the quality of the education for the health science students in the future. To fill such void, the present study was designed to explore the hopes and needs of the health students in online learning during the COVID-19 pandemic.

\section{Methods}

\section{Design}

A qualitative content analysis approach was used to explore the opinions and experiences of the health students. Qualitative content analysis was used because it classifies texts into categories by systematically coding and identifying themes or patterns in the text to understand the study phenomena.

\section{Participants}

The participants involved were six health science students in a private Muslim University in Yogyakarta, Indonesia. They were recruited using a purposive sampling technique based on some criteria, including (1) active students, (2) aged at least 18 years old, and (3) in a conscious state and not suffer from physical illnesses. The exclusion criteria were students who were sick and were not able to be interviewed.

\section{Data collection}

The data were garnered through in-depth interviews (40-60 min long). We also employed field notes to capture conditions that emerged during the interview sessions. The interviews were conducted through video call and recorded based on participants' informed consent.

\section{Rigor}

The trustworthiness of this qualitative study was ensured by four criteria: Credibility, dependability, transferability, and confirmability [16]. Credibility was promoted by the researchers' prior engagement with the students who have experienced with online learning methods. Member checks were also used, that is, the results were brought back for the participants to confirm. Dependability and confirmability of the data were enhanced by keeping an audit trail, peer debriefing, and using reflexive journals to record ideas and thoughts regarding whether the data were collected sufficiently, appropriateness of data coding and categorization in data collection, and research meetings. Finally, transferability of the data was established by rich descriptions of the contextual conditions of the study phenomena.

\section{Ethical consideration}

The study was approved by the research ethics committee of the UNISA University (1720/ KEP-UNISA/X/2020). All participants provided written informed consent before conducting the interviews

\section{Data analysis}

Colaizzi technique was used to analyze the data. Tape recordings and field notes were transcribed verbatim. The transcripts for each participant were coded separately to capture individual experiences and were first read repeatedly. The transcripts were examined for three types of codes: Descriptive, interpretative, and patterns. Interpretive codes involving the researcher's interpretation were also used based on the research purpose. Then, these researchers independently coded the data until agreement was over $95 \%$, and both within- and across-case analyses were used.

\section{Findings}

The findings of this study are elaborated into two major themes: The students' expectations on the online learning (hopes on learning issues and lecturer performance) and the students' need in the online learning (family support and internet network facility). 


\section{The students' expectations for online learning in the COVID-19 era}

\section{Hope on learning}

In this theme, most of the students preferred to learn offline since they believe that the lessons taught would be better understood. Furthermore, they commented that multiple learning methods enacted in the classrooms are necessary such as the use of video and the evaluation of learning during COVID-19 pandemic. These issues are depicted in the interview as follows:

It's better to learn offline than online. (P1)

Better understand the material if it is delivered face to face, better understanding. (P6)

It is recommended that learning is combined online and offline. Practical learning should be offline because it requires special skills. (P4)

In e-learning learning, I hope that the lecturer will explain the material in the form of a video. After that, the video is uploaded on the learning so that it can be watched again by the students. (P4)

In practicum learning, we are more comfortable using videos because we can replay the video to better understand it. I hope that the lecturers and the students must conduct a joint evaluation of this online learning. (P2)

\section{Expectations on the lecturers}

With regard to the expectation on the lecturers' performance, the majority of the students commented on the lecturers' attitudes and assignments. The students consider that well-shaped communication, guidance, and tolerance during the online learning are necessary. For example, the students expect that the lecturers tolerate them in submitting the assignments late due to error internet connection. These issues are seen in the interview:

The point is that the lecturer embraces the students more, sometimes there is substance, sometimes the response takes a long time. Then, sometimes the lecturer may also have to understand the students better and find a solution, uploading it sometimes is late due to the signal. (P1)

The task does not need to be many. (P3)

The participants also expect the lecturers to prepare good online teaching techniques. The lecturers did not confirm suddenly because the students were not ready when the class schedule was announced in a short time. During the online learning at home, the students' activities include helping parents with assignments so that the information on the class schedules should be informed in advance. The participants also hoped that the lecturers would not be too serious when teaching but would teach humorously to reduce the students' stress, as stated below:

With a joke, do not be too serious when explaining the material, to reduce student stress. (P5)

I hope the lecturer does not give the confirmation in the middle of the night. If there is a lecture, please inform immediately. (P5)

\section{The students' needs in learning in the COVID-19 era}

The students' needs in learning in the COVID-19 era fall into two themes: Family support and network support.

\section{Family support}

The students need support from their families in the form of attention and understanding while they are undergoing the online learning. Participants need family support to support online learning. The assistance is in the form of support in the form of parents' willingness to become partners in practicum activities, making videos, and partners in making videos, as expressed as follows:

Sometimes when I am confused about finding a partner for practicum activities, I ask my parents to be willing to be friends in making videos or partners in making the video. (P2)

The participants also need family support in other forms, namely, nutritional and financial support, to install Wi-Fi in the boarding houses. Parents' attention really helps the online learning process, for example, by providing breakfast, lunch, and other nutritional needs during the online learning, as expressed as follows:

My mother gets angry when I do not have breakfast, do not eat lunch, then she goes on strike and does not want to cook again the next day. (P5)

\section{Internet network support}

The supports are quota support in the form of quota assistance and a good network to support online learning. The students are very grateful for the quota assistance from the government through the campus in supporting the online learning. The need for an internet network is an important factor in the online learning. The existence of internet quota assistance for the students from the government really helped the smooth running of the student learning during the pandemic period, as stated as follows: 
The first is the network. (P6)

Now there are subsidies so it is rather light. (P1)

Alhamdulillah, yesterday there was also assistance from the government in the form of free data package, which really spurred students to be even more active in these online activities. ( $P 2)$

\section{Discussion}

\section{The expectations of the health students during the online learning in COVID-19 pandemic}

Based on the results of the analysis, we identified two students' expectations in the online learning during the pandemic. First, the expectations for learning and second is expectations for the lecturers. Hope in learning is found by the students to verbalize their desire to learn offline because they have no experience doing full online learning. The students who have no previous experience in online learning will have thoughts and perceptions that online learning is highly unwanted by the students [17]. Following the research conducted by Hermida (2020), the students prefer offline learning because the students think that taking online learning is an unpleasant experience and the students show a negative attitude toward online learning [18]. The students consider online learning to be more difficult in accessing learning and assignments, it is difficult to focus on learning for a long time so they prefer offline learning. The finding of this study also corresponds to the research done by Amir et al. (2020), showed that most students prefer offline learning because online learning makes communication more difficult and less satisfying in learning [19]. However, online learning is more efficient because there is more time to study and review learning materials. This study is not in line with the research done by Khalil et al. (2020) that the health students prefer online learning compared to offline learning because the online learning process is already running very well, thus suggesting the use of permanent online learning [20].

The findings of this study indicate that students expect a variety of learning methods in online and offline mode (blended learning). Supported by a research conducted by Amir et al. (2020), the students strongly agree if the learning process is carried out in a blended online and offline mode so that the COVID-19 pandemic can change the future learning strategies and not only change the use of technology in education [19]. Blended learning will increasingly make students perceive varied learning styles and be more independent in learning like the adult learning [21]. Blended learning for the health students for the theory learning can be done online and for practicum could be done offline [22]. A study by Westerlaken et al. (2019) revealed that blended learning can make learning more effective and make the students more active in the learning process [23]. However, according to Jebraeily et al. (2020), blended learning process has shortcomings such as technical, organizational, human resource infrastructure constraints, and a lack of readiness [24]. Therefore, blended learning is like a double-edged knife that requires a thorough review of the strengths, opportunities, weaknesses, and threats.

The health students also expect the use of video in the learning process, especially in practicum, so that the students can practice repeatedly at home to practice their skills. The unavailability of virtual laboratories makes the students and the lecturers have to take advantage of the existing platform to enter demonstration videos conducted by the lecturers of the learning to be delivered that can be seen by the students [25]. According to Iménez-Rodríguez et al. (2021), practicum learning through videos will stimulate the students' ability to try to practice at home repeatedly compared to just the theory [26]. Video learning in practicum utilizes audio and visuals so that it will be easier for the students to understand than audio or visual only [27]. The way for the students to study independently is that after the students watch the video the students will be divided into small groups and each individual tries to make a practical video to practice their skills [28]. According to Puljak et al. (2020) recently it shows that the students really hope for the lecturers to record the online lectures and the recording can be seen by the students so that they can re-study the material that has been delivered [29]

Another hope of the students is that there is a learning evaluation that will involve the students, lecturers, and staff in educational institutions. The students are involved in providing an evaluation of the learning process that has been carried out during the pandemic because the students are the consumers of education. Evaluation can be done with a questionnaire for all students as well as several selected student representatives to convey their aspirations directly, such as using a focus group discussion [30]. The evaluation from the students is expected to be an input for improving the quality of the lecturers and staff. Educational institutions can provide the best service for the students by improving the quality of human resources, facilities and infrastructure, adequate curriculum, and studentcentered online learning modalities [31]. A study by Rapanta et al. (2020) was informed that the learning process followed by an evaluation is very important to do considering the number of students has decreased drastically during the pandemic period [30]. The evaluation process will be the feedback so that the educational institutions around the world can (again) be competitive so that the evidence of managers' readiness is needed in terms of professionalism. 
The students' expectations for the lecturers during the online learning include lecturers' attitudes and assignments. The students expect that the lecturers' attitude in scheduling will not be too busy. In line with the research conducted by Khalil et al (2020), the scheduling of the lectures during the COVID-19 pandemic was too busy in a day, making the students feel bored and unable to properly digest what was conveyed by the lecturers, and making the students have to face the computer almost all day long [20]. In addition, the students also expect the lecturers to provide a fast and correct answer of the questions they asked. The finding of this study is in line with the previous research from Mishra et al. (2020), they uncovered that the students would be very happy if during the COVID-19 pandemic, they built a very good relationship with the lecturers through direct communication, both for discussion and conveying complaints to reduce stress [32]. According to Amir et al. (2020), during the COVID-19 pandemic, the students found it difficult to communicate with their supervisors [19].

The students also hope that the lecturers do not give too many assignments and tolerate delays in submitting assignments because it could be a network factor that is not supportive. This claim is supported by Son et al. (2020) contending that $31 \%$ of health students felt that they were given too many assignments and were difficult to do [33]. This research is not in line with Puljak et al. (2020) who stated that the students are excited with the assignments and homework given by the lecturers because it helps the students understanding the course material better [29]. The conditions of the COVID-19 pandemic make the lecturers have to tolerate the students who do not submit the assignments on time because of the inhibiting factors faced by the students, such as blackouts or internet problems, and giving assignments that are not a burdensome [34]. A study showed the undergraduate nursing students considered having online learning to be very stressful (47.2\%) and had correlation with online learning satisfaction [35], and the students were less active during online classes compared to the traditional classes [36]. It is implied that the students have problem and thus have an expectation in the problem solving for the online learning.

\section{Support for health students during online learning in pandemic COVID-19}

The second theme analysis found was the support, including family support and network support. Family support is very important for the students in pursuing education during the COVID-19 pandemic. Based on previous research by Lee et al. [37], family support can be a factor in the students completing education or being expelled from educational institutions. The students who have good family support will complete their education well. Family support, including the involvement of the parents in pursuing higher education, is very important for the students. Adult students also need parental guidance and counseling up to the university level as there are major changes in learning styles and environments from school to university [38]. Even the research conducted on students with lower-middle class economies shows that family emotional support plays an important role in encouraging positive academic results because it improves psychological well-being. Another study reported that the students gained the family members' support during their e-learning experienced high levels of learning engagement and they felt having the capacity to devote themselves in learning. Moreover, family members play an important role as the observers of the students' resilience and personal development. In addition, social supports are identified as important for the student engagement [41]. Financial support is not related to positive academic results that family support can be a factor in students completing education or being expelled from educational institutions. The students who have good family support will complete their education well. Family support, including the involvement of the parents in pursuing higher education, is very important for the students. Adult students also need parental guidance and counseling up to the university level as significant changes in learning styles and environments from school to university [42].

Second, network (internet connection) support is considered as a crucial part. A study showed that the majority of the students had internet problems and technological issues [43], [44], interrupted internet connection, unfeasible practical natured courses, load shedding, etc., were perceived as obstacles to online learning [45]. The network support referred to is internet quota assistance and smooth networks to support learning. Internet quota during online learning becomes an obstacle in the learning process. Inline with the research from Amir et al. [19] that the students' complain about the unstable internet connections and the internet quotas which increase the financial burdens, thus both become an infrastructure problem. This finding is also supported by Alsoufi et al. [46] that $78.3 \%$ of the students thought that it would be difficult to attend online lectures due to financial costs, especially because of the civil war and financial crisis in Libya despite good $4 \mathrm{G}$ networks. The existence of a form of internet network support in the form of internet quota assistance from the Indonesian Ministry of Education and Culture every month helps students taking online learning. This quota assistance makes students save on buying internet quotas, especially quotas for virtual meetings that consume quite a lot of quota. The limitation of this study is that this study only describes health students (nursing) at the academic stage, not yet describing health students at the clinical practice or professional level program. 


\section{Conclusions}

COVID-19 has made that the health students have to do online learning since March 15, 2020. During the online learning, the results of qualitative research obtained two themes related to the expectations of the health students in undergoing the online learning, including the expectations of learning and expectations of lecturers. The students expect the learning to be done in an online-offline combination. Offline learning is for the practicum method. The students also expect the lecturers' understanding during online learning. There are two themes for the students' needs during the online learning, including family support and network support. Educational institutions, governments, and families must ensure the needs and support needed by health students so that the educational process can run smoothly. Several steps must be taken into account in the online learning process, namely, developing a supportive curriculum, adequate human resources, and quality electronic systems.

\section{References}

1. Rothan HA, Byrareddy SN. The epidemiology and pathogenesis of Coronavirus disease (COVID-19) outbreak. J Autoimmun. 2020;109:102433. https://doi.org/10.1016/j.jaut.2020.102433 PMid:32113704

2. WHO. WHO Announces COVID-19 Outbreak a Pandemic. Geneva: World Health Organization; 2020.

3. WHO. Coronavirus Disease 2019 (COVID-19) Situation Report-94. Geneva: World Health Organization; 2021.

4. Satgas COVID-19. Satgas Penanganan COVID-19, Satgas COVID-19; 2021.

5. Bedford J, Enria D, Giesecke J, Heymann DL, Ihekweazu C, Kobinger G, et al. COVID-19: Towards controlling of a pandemic. Lancet. 2020;395(10229):1015-8. https://doi.org/10.1016/ S0140-6736(20)30673-5

PMid:32197103

6. UNESCO. School Closures Caused by Coronavirus (COVID-19). London, United Kingdom: UNESCO; 2020.

7. Nicola M, Alsafi Z, Sohrabi C, Kerwan A, Al-Jabir A, losifidis C, et al. The socio-economic implications of the Coronavirus pandemic (COVID-19): A review. Int J Surg. 2020;78:185-93. https://doi.org/10.1016/j.ijsu.2020.04.018

PMid:32305533

8. UNESCO. Universities Tackle the Impact of COVID-19 on Disadvantaged Students. London, United Kingdom: UNESCO;2020.

9. Apuke OD, lyendo TO. University students' usage of the internet resources for research and learning: Forms of access and perceptions of utility. Heliyon. 2018;4(12):e01052. https://doi. org/10.1016/j.heliyon.2018.e01052

PMid:30582057

10. Dhawan S. Online learning: A panacea in the time of COVID-19 crisis. J Educ Technol Syst. 2020;2020(1):5-22. https://doi. org/10.1177/0047239520934018
11. Mian A, Khan S. Medical education during pandemics: A UK perspective. BMC Med. 2020;18(1):100. https://doi.org/10.1186/ s12916-020-01577-y PMid: 32268900

12. Ross DA, National Neuroscience Curriculum Initiative "Quarantine Curriculum" Committee. Creating a "quarantine curriculum" to enhance teaching and learning during the COVID-19 pandemic. Acad Med. 2020;95(8):1125-6. https://doi. org/10.1097/ACM.0000000000003424 PMid:32744816

13. Chandra S, Laoteppitaks C, Mingioni N, Papanagnou D. Zooming-out COVID-19: Virtual clinical experiences in an emergency medicine clerkship. Med Educ. 2020;54(12):1182-3. https://doi.org/10.1111/medu.14266 PMid:32502282

14. Urooj U. Expectations, fears and perceptions of doctors during COVID-19 pandemic. Pak J Med Sci. 2020;36(COVID19S4):S37-42. https://doi.org/10.12669/pjms.36.COVID19-S4.2643 PMid:32582312

15. Eringfeld S. Higher education and its post-coronial future: Utopian hopes and dystopian fears at Cambridge University during COVID-19. Stud High Educ. 2021;46(1):146-57.

16. Elo $S$, Kääriäinen $M$, Kanste $O$, Pölkki T, Utriainen $K$, Kyngäs $H$. Qualitative content analysis. SAGE Open. 2014;4(1):1-10.

17. Bernard RM, Abrami PC, Borokhovski E, Wade CA, Tamim RM, Surkes MA, et al. A meta-analysis of three types of interaction treatments in distance education. Rev Educ Res. 2009;79(3):1243-89.

18. Aguilera-Hermida AP. College students' use and acceptance of emergency online learning due to COVID-19. Int $J$ Educ Res Open. 2020;1:100011. https://doi.org/10.1016/j. ijedro.2020.100011

19. Amir LR, Tanti I, Maharani DA, Wimardhani YS, Julia V, Sulijaya B, et al. Student perspective of classroom and distance learning during COVID-19 pandemic in the undergraduate dental study program Universitas Indonesia. BMC Med Educ. 2020;20(1):392.

20. Khalil R, Mansour AE, Fadda WA, Almisnid K, Aldamegh M, Al-Nafeesah $A$, et al. The sudden transition to synchronized online learning during the COVID-19 pandemic in Saudi Arabia: A qualitative study exploring medical students' perspectives. BMC Med Educ. 2020;20(1):285. https://doi.org/10.1186/ s12909-020-02208-z

PMid:32859188

21. Murad MH, Coto-Yglesias F, Varkey P, Prokop LJ, Murad AL, Murad $\mathrm{MH}$, et al. The effectiveness of self-directed learning in health professions education: A systematic review. Med Educ. 2010;44(11):1057-68. https://doi. org/10.1111/j.1365-2923.2010.03750.x PMid:20946476

22. Liu Q, Peng W, Zhang F, Hu R, Li Y, Yan W. The effectiveness of blended learning in health professions: Systematic review and meta-analysis. J Med Internet Res. 2016;18(1):e2. https://doi. org/10.2196/jmir.4807

PMid:26729058

23. Westerlaken M, Christiaans-Dingelhoff I, Filius RM, de Vries B, de Bruijne M, van Dam M. Blended learning for postgraduates; an interactive experience. BMC Med Educ. 2019;19(1):289. https://doi.org/10.1186/s12909-019-1717-5 PMid:31362735

24. Jebraeily M, Pirnejad H, Feizi A, Niazkhani Z. Evaluation of blended medical education from lecturers' and students' viewpoint: A qualitative study in a developing country. BMC Med Educ. 2020;20(1):482. https://doi.org/10.1186/s12909-020-02388-8 PMid:33256714 
25. Hilburg R, Patel N, Ambruso S, Biewald MA, Farouk SS. Medical education during the Coronavirus disease-2019 pandemic: Learning from a distance. Adv Chronic Kidney Dis. 2020;27(5):412-7. https://doi.org/10.1053/j.ackd.2020.05.017 PMid:33308507

26. Jiménez-Rodríguez D, Arrogante $O$. Simulated video consultations as a learning tool in undergraduate nursing: Students' perceptions. Healthcare (Basel). 2020;8(3):280. https://doi.org/10.3390/healthcare8030280 PMid:32825269

27. Bal-Gezegin B. An investigation of using video vs. audio for teaching vocabulary. Proc Soc Behav Sci. 2014;143:450-7.

28. Shih KC, Chan JC, Chen JY, Lai JS. Ophthalmic clinical skills teaching in the time of COVID-19: A crisis and opportunity. Med Educ. 2020;54(7):663-4. https://doi.org/10.1111/medu.14189 PMid:32324929

29. Puljak L, Čivljak M, Haramina A, Mališa S, Čavić $D$, Klinec $D$, et al. Attitudes and concerns of undergraduate university health sciences students in Croatia regarding complete switch to e-learning during COVID-19 pandemic: A survey. BMC Med Educ. 2020;20(1):416. https://doi.org/10.1186/ s12909-020-02343-7

PMid:33167960

30. Rapanta C, Botturi L, Goodyear P, Guàrdia L, Koole M. Online university teaching during and after the COVID-19 crisis: Refocusing teacher presence and learning activity. Postdigit Sci Educ. 2020;2(3):923-45.

31. Mukhtar K, Javed K, Arooj M, Sethi A. Advantages, limitations and recommendations for online learning during COVID-19 pandemic era. Pak J Med Sci. 2020;36(COVID19-S4):S27-31. https://doi.org/10.12669/pjms.36.COVID19-S4.2785 PMid:32582310

32. Mishra L, Gupta T, Shree A. Online teaching-learning in higher education during lockdown period of COVID-19 pandemic. Int J Educ Res Open. 2020;1:100012.

33. Son C, Hegde S, Smith A, Wang X, Sasangohar F. Effects of COVID-19 on college students' mental health in the United States: Interview survey study. J Med Internet Res. 2020;22(9):e21279. https://doi.org/10.2196/21279 PMid:32805704

34. Oyedotun TD. Sudden change of pedagogy in education driven by COVID-19: Perspectives and evaluation from a developing country. Res Glob. 2020;2:100029.

35. Oducado RM, Estoque H. Online learning in nursing education during the COVID-19 pandemic: Stress, satisfaction, and academic performance. J Nurs Pract. 2021;4(2):143-53.

36. Bączek M, Zagańczyk-Bączek M, Szpringer M, Jaroszyński A, Wożakowska-Kapłon B. Students' perception of online learning during the COVID-19 pandemic: A survey study of Polish medical students. Medicine (Baltimore). 2021;100(7):e24821. PMid:33607848

37. Lee $\mathrm{Y}$, Choi J, Kim T. Discriminating factors between completers of and dropouts from online learning courses. $\mathrm{Br} J$ Educ Technol. 2013;44(2):328-37. https://doi. org/10.1111/j.1467-8535.2012.01306.x

38. Shahzadi MA, Mahmood A. Parents involvement at university level education: Students perception in under developing country. Eur Sci J. 2016;12(22):294.

39. Gao H, Ou Y, Zhang Z, Ni M, Zhou X, Liao L. The relationship between family support and E-learning engagement in college students: The mediating role of e-learning normative consciousness and behaviors and self-efficacy. Front Psychol. 2021;12:573779. https://doi.org/10.3389/fpsyg.2021.573779 PMid:33613373

40. Sururin S, Mahmuda MC, Muslim M. Family engagement in nurturing students' resilience during remote learning in COVID-19 pandemic. TARBIYA J Educ Muslim Soc. 2020;7(2):204-16. Available from: http://www.journal.uinjkt. ac.id/index.php/tarbiya/article/view/20582 [Last accessed on 2022 Jan 10].

41. Koob C, Schrö Pfer K, Coenen M, Kus S, Schmidt N. Factors influencing study engagement during the COVID-19 pandemic: A cross-sectional study among health and social professions students. PLoS One. 2021;16(7):e0255191. https://doi. org/10.1371/journal.pone.0255191

PMid:34314450

42. Roksa J, Kinsley P. The role of family support in facilitating academic success of low-income students. Res High Educ. 2019;60(4):415-36.

43. Thapa P, Bhandari SL, Pathak S. Nursing students' attitude on the practice of e-learning: A cross-sectional survey amid COVID-19 in Nepal. PLoS One. 2021;16(6):e0253651. https://doi.org/10.1371/journal.pone.0253651

PMid:34166444

44. Mukasa J, Otim M. Nursing students ' perspectives and readiness to transition to E-learning during COVID-19 in the UAE: A crosssectional study. Adv Med Educ Pract. 2021;12:1505-12.

45. Rana S, Garbuja CK, Rai G. Nursing students' perception of online learning amidst COVID-19 pandemic. J Lumbini Med Coll. 2021;9(1):6.

46. Alsoufi A, Alsuyihili A, Msherghi A, Elhadi A, Atiyah $H$, Ashini A, et al. Impact of the COVID-19 pandemic on medical education: Medical students' knowledge, attitudes, and practices regarding electronic learning. PLoS One. 2020;15(11):e0242905. https:// doi.org/10.1371/journal.pone.0242905

PMid:33237962 